\title{
Spontaneous Splenic Rupture in an III Returned Traveller
}

\author{
David FGJ Wolthuis ${ }^{1}$, Ron W Bosboom², Robert-Jan Hassing ${ }^{1}$ \\ ${ }^{1}$ Internal Medicine, Rijnstate Ziekenhuis, Arnhem, the Netherlands \\ ${ }^{2}$ Microbiology Department, Rijnstate Ziekenhuis, Arnhem, the Netherlands
}

Received: $16 / 07 / 2020$

Accepted: $19 / 07 / 2020$

Published: 18/09/2020

How to cite this article: Wolthuis DFGJ, Bosboom RW, Hassing RJ. Spontaneous splenic rupture in an ill returned traveller. EJCRIM 2020;7: doi:10.12890/2020_001891.

Conflicts of Interests: The Authors declare that there are no competing interests.

This article is licensed under a Commons Attribution Non-Commercial 4.0 License

\section{ABSTRACT}

Spontaneous splenic rupture is a known, but rare and possibly fatal, complication of different infectious diseases. We present a case of a 38-year-old male patient who presented with fever, icterus and spontaneous splenic rupture after a visit to Vietnam and discuss the differential diagnosis of splenic rupture in ill returned travellers.

\section{LEARNING POINTS}

- Spontaneous splenic rupture is a rare complication of several tropical diseases, including Salmonella infection.

- Atypical presentations of Salmonella infection should always be considered in febrile ill returned travellers.

\section{KEYWORDS}

Salmonella, fever, spleen, rupture, spontaneous

\section{CASE DESCRIPTION}

A 38-year-old male patient presented with fever and icterus 3 weeks after returning from travelling through Vietnam for 1 month. Complaints started 2 weeks after his return and consisted of fever with cold sweats, which were mainly present during the evenings and at night. Furthermore, he had lost 3-4 kg since his return. He did not have any rash but was itching all over his body for 1 day. He denied any history of abdominal trauma. There were no gastrointestinal, respiratory, circulatory, urogenital or motoric complaints. Prior to the journey he was vaccinated according to recommendations, including receiving the diphtheria, pertussis, tetanus vaccine and the hepatitis $A$ vaccine. Typhoid vaccination was not indicated. In Vietnam he travelled with friends, did not have sexual intercourse, swam once in moving fresh water, did a jungle tour and did not visit any hospitals. The group ate at local street shops, including consumption of pork and seafood. Upon physical examination he was febrile $\left(39.2^{\circ} \mathrm{C}\right)$, and had a blood pressure of $118 / 66 \mathrm{mmHg}$ with a tachycardia of $95 \mathrm{bpm}$. Examination of the abdomen was normal; specifically, no abdominal tenderness and no hepato- or splenomegaly was found. No other abnormalities were present during the physical and neurological examination besides a mild icterus.

The full blood picture showed normal leucocytes (6.8 $\left.\times 10^{9} / \mathrm{I} ; \mathrm{N} \mathrm{4.0}-11.0 \times 10^{9} / \mathrm{l}\right)$, but an increased ESR (49 mm/h; N 1-20 mm/h) and CRP (191 mg/l; $\mathrm{N}<10 \mathrm{mg} / \mathrm{l})$. In addition, elevated bilirubin ( $66 \mu \mathrm{mol} / \mathrm{l} ; \mathrm{N}<21 \mu \mathrm{mol} / \mathrm{I})$, direct bilirubin $(62 \mu \mathrm{mol} / \mathrm{l} ; \mathrm{N}<5 \mu \mathrm{mol} / \mathrm{I}), \mathrm{AF}(289 \mathrm{U} / \mathrm{l} ; \mathrm{N}<120$ $\mathrm{U} / \mathrm{I}$ ) and GGT (289 U/I; $\mathrm{N}<55 \mathrm{U} / \mathrm{I}$ ) were found. ASAT (34 U/I; $\mathrm{N}<35 \mathrm{U} / \mathrm{I}$ ) and ALAT (45 U/I; $\mathrm{N}<45 \mathrm{U} / \mathrm{I}$ ) were not elevated. Abdominal ultrasound revealed an enlarged spleen with suspicion of splenic bleeding without active blood loss. This was confirmed by a CT scan (Fig. 1). A blood slide did not show any malaria parasites. Ceftriaxone $2 \mathrm{~g}$ daily intravenously was initiated because the patient was suspected to be suffering from enteric fever. Blood culture and faecal culture revealed Salmonella Paratyphi B var. Java sensitive to ciprofloxacin after which the 
antibiotic treatment was switched. The patient was discharged from the hospital 6 days after admission. The antibiotic treatment was prolonged because secondary infected haematoma could not be excluded. He recovered well and after 8 weeks of antibiotic treatment his inflammation markers (BSE, CRP) were normalized and ultrasound showed no abnormalities of the spleen. Ciprofloxacin was discontinued without relapse of the disease and faecal cultures remained negative.

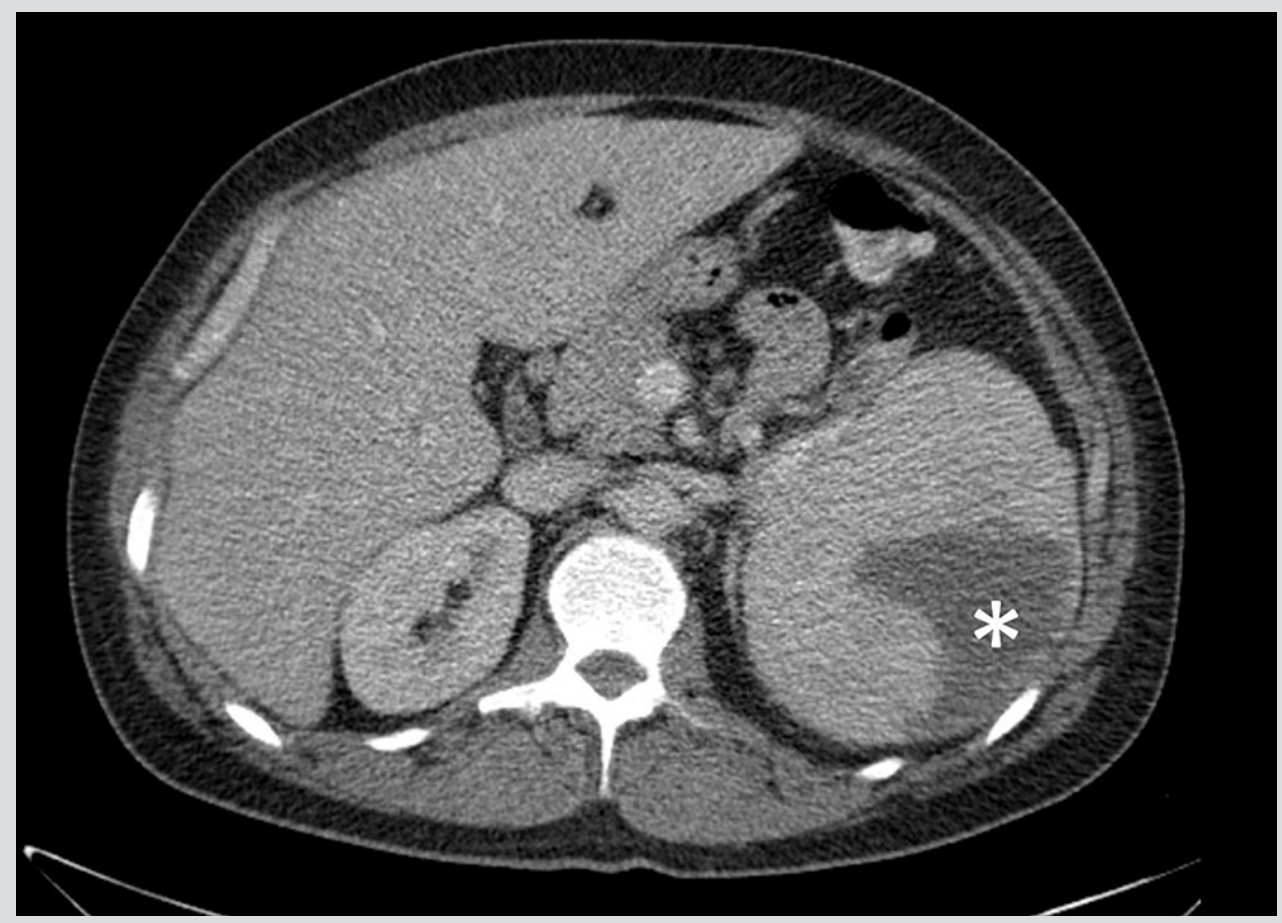

Figure 1. CT scan of the patient at presentation. The splenic rupture is indicated by the asterisk (*)

\section{DISCUSSION}

Spontaneous splenic rupture is a very rare complication of systemic Salmonella infection. Salmonella is known for its remarkable presentations, such as osteitis, aortitis and abscesses ${ }^{[1]}$. In cases of splenic rupture in Salmonella infections, the causative organism is predominately Salmonella Typhi or Paratyphi ${ }^{[2-5]}$. Splenomegaly is a more common feature of systemic Salmonella infection, although this is also a typical sign or clinical feature of typhoidal Salmonella infections. Salmonella Paratyphi B var. Java is classified as a non-paratyphoidalSalmonella organism, although it shares the same somatic and flagellar antigens as Salmonella Paratyphi B. It differs from Salmonella Paratyphi B in using $\mathrm{d}$-tartrate as a carbon source. Usually, the clinical presentation of Salmonella Paratyphi B var. Java is less virulent, but systemic infection has been described ${ }^{[6]}$. In our patient, the systemic Salmonella infection probably caused splenomegaly and spontaneous splenic rupture at the time of the acute infection as a result of a soft and swollen spleen. Due to the bacteraemia, the splenic haematoma was probably secondarily infected with Salmonella, which resulted in the second illness starting 2 weeks after the patient's return.

Spontaneous splenic rupture is a rare complication of different tropical diseases where fever is an important feature (Table 1). Most importantly, malaria is known to lead to spontaneous splenic rupture. Plasmodium falciparum and Plasmodium vivax are the main causes of this possibly lethal complication, but Plasmodium ovale can also cause rupture of the spleen ${ }^{[7]}$. Interestingly, the clinical course before occurrence of the rupture may be asymptomatic. Another parasitic disease spread by mosquitoes associated with fever and spontaneous splenic rupture is leishmaniasis ${ }^{[8]}$.

In our patient, the rupture was caused by a bacterial infection. The most important tropical infection associated with splenic rupture is tuberculosis. However, this usually only develops after a longer incubation period ${ }^{[9,10]}$. Other rare bacterial tropical diseases associated with splenic rupture are brucellosis ${ }^{[11]}$ and relapsing fever, caused by Borrelia recurrentis ${ }^{[12]}$.

Rupture of the spleen due to infectious causes is most commonly seen in viral infections. Infectious mononucleosis is best known for this complication ${ }^{[13]}$. However, other viral diseases may also lead to splenic rupture, including human immunodeficiency virus (HIV) infection ${ }^{[14,15]}$, dengue fever ${ }^{[16,17]}$ and hepatitis $A^{[18,19]}$. 


\begin{tabular}{|c|c|}
\hline Bacterial & $\begin{array}{c}\text { Tuberculosis } \\
\text { Borrelia recurrentis (relapsing fever) } \\
\text { Salmonella (typhoidal and non-typhoidal) } \\
\text { Brucellosis }\end{array}$ \\
\hline Viral & $\begin{array}{c}\text { Epstein-Barr virus (EBV) } \\
\text { Human cytomegalovirus (HCMV) } \\
\text { Human immunodeficiency virus (HIV) } \\
\text { Dengue } \\
\text { Hepatitis A }\end{array}$ \\
\hline Parasitic & $\begin{array}{c}\text { Malaria (Plasmodium falciparum, P. vivax, P. ovale) } \\
\text { Leishmaniasis }\end{array}$ \\
\hline
\end{tabular}

Table 1. Infectious causes of spontaneous splenic rupture in ill returned travellers

\section{CONCLUSION}

Spontaneous splenic rupture is a known, but rare and possibly fatal, complication of different tropical infectious diseases. We should be aware of the possibility of splenic rupture in febrile ill returned travellers. We describe a very rare case of spontaneous splenic rupture caused by systemic Salmonella infection. Atypical presentations of Salmonella infection should always be considered in febrile ill returned travellers.

\section{REFERENCES}

1. Crump JA, Sjolund-Karlsson M, Gordon MA, Parry CM. Epidemiology, clinical presentation, laboratory diagnosis, antimicrobial resistance, and antimicrobial management of invasive Salmonella infections. Clin Microbiol Rev 2015;28(4):901-937.

2. Witczak W. [A case of splenic rupture during typhoid fever]. Przegl Epidemiol 1969;23(2):349-351.

3. Azkarate I, Amato E, Neira F, Gorospe A. [Spontaneous splenic rupture secondary to Salmonella typhi infection]. Enferm Infecc Microbiol Clin 1993;11(1):54-55.

4. Ali G, Kamili MA, Rashid S, Mansoor A, Lone BA, Allaqaband GQ. Spontaneous splenic rupture in typhoid fever. Postgrad Med J 1994;70(825):513-514.

5. Julia J, Canet JJ, Lacasa XM, Gonzalez G, Garau J. Spontaneous spleen rupture during typhoid fever. Int J Infect Dis 2000;4(2):108-109.

6. Hernandez E, Rodriguez JL, Herrera-Leon S, Garcia I, de Castro V, Muniozguren N. Salmonella Paratyphi B var Java infections associated with exposure to turtles in Bizkaia, Spain, September 2010 to October 2011. Euro Surveill 2012;17(25):20201.

7. Lemmerer R, Unger M, Vossen M, Forstner C, Jalili A, Starzengruber P, et al. Case report: spontaneous rupture of spleen in patient with Plasmodium ovale malaria. Wien Klin Wochenschr 2016;128(1-2):74-77.

8. Rovira RE, Diaz-Gomez JR, Lapuebla X, Aguar MC. [Spontaneous rupture of the spleen in a patient with visceral leishmaniasis]. Enferm Infecc Microbiol Clin 2005;23(5):327.

9. Fegan D, Butcher C, Rees C, Glennon J. Tuberculosis and abdominal pain. Intern Med J 2005:35(7):437-438.

10. Safioleas MC, Stamatakos MC, Safioleas CM, Diab Al, Agapitos EB. Co-existence of spontaneous splenic rupture and tuberculosis of the spleen. Saudi Med J 2006;27(10):15881590.

11. Demirdal T, Okur N, Demirturk N. Spontaneous splenic rupture with hematoma in a patient with brucellosis. Chang Gung Med J 2011;34(6 Suppl):52-55.

12. Legerton CW, Chambers WL. Spontaneous rupture of the spleen in relapsing fever. U S Armed Forces Med J 1950;1(1):88-90.

13. Bartlett A, Williams R, Hilton M. Splenic rupture in infectious mononucleosis: a systematic review of published case reports. Injury 2016;47(3):531-538.

14. Barrier JH, Bani-Sadr F, Gaillard F, Raffi F. Spontaneous rupture of the spleen revealing primary human immunodeficiency virus infection. Clin Infect Dis 1997;25(2):336-337.

15. Mirchandani HG, Mirchandani IH, Pak MS. Spontaneous rupture of the spleen due to acquired immunodeficiency syndrome in an intravenous drug abuser. Arch Pathol Lab Med 1985;109(12):1114-1116

16. Redondo MC, Rios A, Cohen R, Ayala J, Martinez J, Arellano G, et al. Hemorrhagic dengue with spontaneous splenic rupture: case report and review. Clin Infect Dis 1997;25(5):1262-1263.

17. Pungjitprapai A, Tantawichien T. A fatal case of spontaneous rupture of the spleen due to dengue virus infection: case report and review. Southeast Asian J Trop Med Public Health 2008;39(3):383-386.

18. Van Landingham SB, Rawls DE, Roberts JW. Pathological rupture of the spleen associated with hepatitis A. Arch Surg 1984;119(2):224-225.

19. Guleria S, Dorairajan LN, Sinha S, Khazanchi R, Bal S, Guleria R. Spontaneous rupture of spleen in viral hepatitis A. Indian J Gastroenterol 1996;15(1):30. 